Med Klin Intensivmed Notfmed 2013.

108:223-233

DOI 10.1007/s00063-013-0224-4

Received: 9 August 2012

Revised: 13 December 2012

Accepted: 25 January 2013

Published online: 3 March 2013

(c) Springer-Verlag Berlin Heidelberg 2013

Redaktion

M. Buerke, Siegen
G. Elke ${ }^{1}$ E. Kuhnt ${ }^{2} \cdot$ M. Ragaller ${ }^{3} \cdot$ D. Schädler ${ }^{1} \cdot$ I. Frerichs ${ }^{1} \cdot$ F.M. Brunkhorst ${ }^{4,5}$. M. Löffler ${ }^{6} \cdot K$. Reinhart ${ }^{4} \cdot N$. Weiler ${ }^{1} \cdot$ for the German Competence Network Sepsis (SepNet)

${ }^{1}$ Department of Anaesthesiology and Intensive Care Medicine, University Medical Centre Schleswig-Holstein, Campus Kiel

${ }^{2}$ Clinical Trial Centre Leipzig, University of Leipzig

${ }^{3}$ Department of Anaesthesiology and Intensive Care Medicine, University Hospital of the Technical University of Dresden

${ }^{4}$ Department of Anaesthesiology and Intensive Care Medicine, Jena University Hospital, Jena

5 Paul-Martini Sepsis Research Group, Jena University Hospital, Jena

${ }^{6}$ Institute of Medical Informatics, Statistics and Epidemiology, University of Leipzig

\section{Enteral nutrition is associated with improved outcome in patients with severe sepsis}

\section{A secondary analysis of the VISEP trial}

\section{Background}

Nutrition is considered as an important therapeutic strategy modulating the metabolic stress response and affecting the clinical outcome of critically ill patients. The use of early enteral nutrition (EN) should be preferred over parenteral nutrition $(\mathrm{PN})$ because it is more physiologic and associated with improved outcome $[14,22]$. EN is, however, frequently characterized by a low caloric intake predominantly in the early phase of underlying disease $[12,25]$. In order to improve energy delivery, an early supplemental use of $\mathrm{PN}$ is proposed [16]. The advantage of the one nutrition type is thereby regarded as the disadvantage of the other, as both have inherent risks of under- or overfeeding. On the one hand, large energy deficits resulting from a low caloric intake during EN may lead to increased infectious complications and a longer intensive care unit (ICU) stay $[10,13,35]$. On the other hand, $\mathrm{PN}$ is associated with nutritional excess leading to hyperglycemia, increased metabolic stress, and infectious morbidity $[9,28]$.

The guidelines of the European Society of Clinical Nutrition and Metabolism
(ESPEN) and the American Society of Parenteral and Enteral Nutrition (ASPEN) promote an early enteral start for nutrition [23,31]. In patients receiving less than their targeted enteral feeding after 2 days, ESPEN recommends to then initiate the use of supplemental PN to achieve the caloric goal. ASPEN recommends retaining supplemental PN until days 7-10, allowing for a reduced caloric intake with EN alone unless the patient was previously malnourished. These guidelines are mainly based on nutritional data available from studies in mixed patient populations, while only few data exist for severely septic patients alone. Hence, the current Surviving Sepsis Campaign guidelines do not include specific nutritional recommendations [8], whereas the German Sepsis Society recommends the preferential use of early EN and the use of a combination of EN and PN if caloric requirements cannot be sufficiently covered with a low-evidence grade E [5]. In a former prospective observational study of $415 \mathrm{pa}-$ tients with severe sepsis or septic shock, we found that the use of PN was associ-

G. Elke and E. Kuhnt contributed equally to this article. 
ated with increased morbidity and mortality [11].

Based on these former results, our present objective was to compare the outcomes of three nutritional strategies (EN vs. PN vs. combined nutrition, i.e., $\mathrm{EN}+\mathrm{PN}$ ) in patients with severe sepsis or septic shock using the database of the "Efficacy of Volume Substitution and Insulin Therapy in Severe Sepsis (VISEP)" trial [4]. In this analysis we only included patients with a length of ICU stay of more than 7 days to avoid the effect that patients with a short ICU stay receive less nutrition and thus confound the effect on outcome $[3,6,18]$.

\section{Methods}

\section{Study design and setting}

This study was conducted as a secondary analysis of the VISEP trial, which was carried out by the German Competence Network Sepsis (SepNet) as a national, multicenter, randomized study with a two-bytwo factorial design comparing intensive insulin therapy with conventional insulin therapy and hydroxyethyl-starch with Ringer's lactate for volume resuscitation. SepNet officially approved the use of the data from the VISEP trial. A detailed description of the original study design is outlined elsewhere [4]. Briefly, patients were recruited from April 2003 to June 2005 in multidisciplinary ICUs at 18 academic tertiary hospitals in Germany. The leading ethics committee of the Friedrich Schiller University of Jena and the responsible ethics committee at each participating institution approved the study. All patients enrolled in the study had to fulfill the inclusion criteria for the presence of infection, systemic inflammatory response syndrome, and organ dysfunction or septic shock based on the consensus criteria of the American College of Chest Physicians and Society of Critical Care Medicine [2]. Patients were deemed to be eligible if the onset of the syndrome was less than $24 \mathrm{~h}$ before or less than $12 \mathrm{~h}$ after admission to the ICU if the condition developed in the ICU, and they were followed up for 90 days to determine outcome measures. All investigators agreed to base their patients' management on the international guidelines for the diagnosis and treatment of severe sepsis [33]. With respect to nutrition therapy, the preferential use of enteral nutrition was recommended. In patients not tolerating EN despite the use of jejunal feeding or with contraindications to enteral nutrition, parenteral nutrition should be used.

For the present analysis we evaluated the nutrition data that were collected daily during the study period of up to 21 days or until death or discharge from the ICU.

\section{Patients}

The intention-to-treat population of the VISEP trial comprised 537 patients with severe sepsis or septic shock. We excluded patients with invalid data on nutrition from our analysis. As proposed by previous studies $[3,6,18]$, we further excluded patients with a length of ICU stay of 7 days or less in order to avoid potential confounding of a short ICU stay on the amount of nutrition therapy and outcome.

Patients were divided into groups according to the types of nutrition used in the VISEP trial, which were identified as exclusively EN, exclusively PN, and combined nutrition therapy $(\mathrm{EN}+\mathrm{PN})$. The latter involved all patients nourished enterally and parenterally either on the same or different treatment days during the study period. Days without EN or PN were included and counted as 0 kcal. The patients' characteristics including demographic data, Acute Physiology and Chronic Health Evaluation II score (APACHE II score), and comorbidities were documented at the time of study entry. In surgical patients, the type of surgery (i.e., abdominal or gastrointestinal surgery) suspected to influence the route of nutrition therapy was also identified at study entry. Data comprising the timing, route, and amount of nutrition, blood glucose, and insulin doses were collected daily during the VISEP study period. The Harris-Benedict equation without activity adjustment was used to calculate the basal energy expenditure (BEE). The mean daily caloric intake was then divided by the BEE in order to estimate the ratio of caloric intake and energy expenditure.
Per protocol, secondary infections were classified according to the onset (microbiologically proven or clinically suspected), origin (community acquired or nosocomial), and site of infection. This was determined by the investigator on site and required daily documentation throughout the study.

\section{Outcome measures}

Clinical outcome was measured by the Sequential Organ Failure Assessment (SOFA), the need for renal-replacement therapy, the duration of mechanical ventilation, the incidence of severe hypoglycemia ( $\leq 40 \mathrm{mg}$ of glucose per deciliter; $2.2 \mathrm{mmol}$ per liter), length of ICU stay, secondary infections, and mortality.

\section{Statistical analysis}

Statistical analyses were performed using SAS software, version 9.1.3 (SAS Institute Inc., Cary, NC, USA). Categorical outcome data were reported as absolute or relative frequencies and tested with the Chi-square test or Fisher's exact test, as appropriate. Continuous data were presented by mean and standard deviation or median and interquartile range and were compared using the $\mathrm{t}$-test, ANOVA, Mann-Whitney U test, or Kruskall-Wallis $\mathrm{H}$ test.

The rate of secondary infections and the length of stay in the ICU as well as mortality at 28 and 90 days were investigated by the Kaplan-Meier method and tested by log rank test in an unadjusted fashion. Multiple Cox regression models were applied for adjusted analyses of time to event data. These analyses included variables relevant for nutrition therapy or prognostic factors for patients with severe sepsis. Predictive factors with a $\mathrm{p}$ value $<0.2$ in the unadjusted model were included in the adjusted Cox regression model.

Two-sided $\mathrm{p}$ values were reported and the level of significance was 0.05 . Statistical analyses followed the intention-totreat principle. 


\section{G. Elke · E. Kuhnt · M. Ragaller · D. Schädler · I. Frerichs · F.M. Brunkhorst · M. Löffler · K. Reinhart · N. Weiler · for the German Competence Network Sepsis (SepNet) \\ Enteral nutrition is associated with improved outcome in patients with severe sepsis. A secondary analysis of the VISEP trial}

Abstract

Introduction. The optimal nutritional strategy remains controversial, particularly in severely septic patients. Our aim was to analyze the effect of three nutritional strategies-enteral (EN), parenteral (PN), and combined nutrition $(\mathrm{EN}+\mathrm{PN})$ - on the outcome of patients with severe sepsis or septic shock. Patients and methods. This secondary analysis of the prospective, randomizedcontrolled, multicenter "Intensive Insulin Therapy and Pentastarch Resuscitation in Severe Sepsis (VISEP)" trial only included patients with a length of stay in the intensive care unit (ICU) of more than 7 days. Besides patient characteristics, data on nutrition therapy were collected daily for up to 21 days. Morbidity as measured by the mean Sequential Organ Failure Assessment (SOFA) score, incidence of secondary infections, renal replacement therapy, ventilator-free days and severe hypoglycemia, length of ICU stay, and mortality at 90 days were compared between the three nutritional strategies.

Results. In all, 353 patients were included in the analysis with the majority (68.5\%) receiving $\mathrm{EN}+\mathrm{PN}, 24.4 \%$ receiving $\mathrm{EN}$, and only $7.1 \%$ receiving $P N$. Median caloric intake was $918 \mathrm{kcal} /$ day (EN), 1,210 kcal/day (PN), and $1,343 \mathrm{kcal} /$ day $(\mathrm{EN}+\mathrm{PN} ; \mathrm{p}<0.001)$. In the latter group, calories were predominantly administered via the parenteral route within the first week. The rate of death at 90 days was lower with EN than with EN+PN ( $26.7 \%$ vs. $41.3 \%$, $p=0.048$ ), as was the rate of secondary infections, renal replacement therapy, and duration of mechanical ventilation. In the adjust- ed Cox regression analysis, the effect on mortality [hazard ratio $(\mathrm{HR})=1.86,95 \%$ confidence interval $(\mathrm{Cl}): 1.16-2.98, \mathrm{p}=0.010]$ and the rate of secondary infections $(H R=1.89$, $95 \% \mathrm{Cl}: 1.27-2.81, \mathrm{p}=0.002$ ) remained different between $\mathrm{EN}$ and $\mathrm{EN}+\mathrm{PN}$.

Conclusion. In patients with severe sepsis or septic shock and prolonged ICU stay, EN alone was associated with improved clinical outcome compared to EN+PN. This hypothesis-generating result has to be confirmed by a randomized-controlled trial in this specific patient population.

\section{Keywords}

Sepsis · Severe sepsis · Enteral nutrition · Parenteral nutrition $\cdot$ Combined nutrition therapy

\section{Enterale Ernährung ist mit einem besseren Verlauf bei Patienten mit schwerer Sepsis assoziiert. Eine Sekundäranalyse der VISEP-Studie}

\section{Zusammenfassung}

Hintergrund. Eine optimale

Ernährungsstrategie für Patienten mit

schwerer Sepsis ist nach wie vor nicht eindeutig geklärt. Wir untersuchten den Einfluss unterschiedlicher Ernährungsstrategien (enteral, EN; parenteral, PN; und kombinierte Ernährung, EN+PN) auf den klinischen Verlauf bei Patienten mit schwerer Sepsis und septischem Schock.

Patienten und Methoden. Die vorliegende Sekundäranalyse der prospektiven, randomisierten, kontrollierten, multizentrischen Studie „Intensive Insulin Therapy and Pentastarch Resuscitation in Severe Sepsis (VISEP)" wurde auf Patienten mit einer Intensivliegedauer > 7 Tage beschränkt. Neben den Patientencharakteristika wurden Daten zur täglichen Ernährungstherapie über einen Zeitraum von bis zu 21 Tagen gesammelt. Der Einfluss auf die Morbidität, gemessen an der Höhe des mittleren SOFA-Scores, die Häufigkeit von Sekundärinfektionen, Nierenersatztherapie, beatmungsfreien Tagen und schweren Hypoglykämien, Länge des Aufenthalts auf der Intensivstation sowie die 90-Tage-Sterblichkeit wurden zwischen den angewendeten Ernährungsstrategien verglichen.

Ergebnisse. Von 353 in die Analyse einbezogenen Patienten erhielten $68,5 \% \mathrm{EN}+\mathrm{PN}$, $24,4 \%$ EN und $7,1 \%$ PN. Die täglich zugeführte Kalorienmenge lag im Median bei $918 \mathrm{kcal}(\mathrm{EN}), 1210 \mathrm{kcal}(\mathrm{PN})$ und $1343 \mathrm{kcal}$ $(E N+P N ; p<0,001)$. Hierbei wurden die Kalorien innerhalb der ersten Woche den Patienten mit EN+PN überwiegend parenteral zugeführt. Die 90-Tage-Sterblichkeit war bei Patienten mit EN verglichen mit EN+PN niedriger ( 26,7 vs. $41,3 \%$; $p=0,048)$, ebenso die Rate infektiöser Komplikationen, die Notwendigkeit einer Nierenersatztherapie wie auch die Beatmungsdauer. In einer u. a. für die Krankheits- schwere adjustierten Cox-Regressionsanalyse blieb der Unterschied im Sterblichkeitsrisiko (Hazard Ratio, HR: 1,86; 95\%-Konfidenzintervall, 95\%-KI: 1,16-2,98; $p=0,010)$ und bei den infektiösen Komplikationen (HR: 1,89; 95\%$\mathrm{KI}: 1,27-2,81 ; \mathrm{p}=0,002)$ zwischen den Patienten mit $\mathrm{EN}+\mathrm{PN}$ und $\mathrm{EN}$ bestehen.

Schlussfolgerung. Bei Patienten mit schwerer Sepsis und prolongierter Intensivliegedauer war EN verglichen mit EN+PN mit einem besseren klinischen Verlauf assoziiert. Diese im Kontext der vorliegenden Sekundäranalyse generierte Hypothese sollte anhand einer randomisiert-kontrollierten Studie in dieser spezifischen Patientenpopulation überprüft werden.

\section{Schlüsselwörter}

Sepsis · Schwere Sepsis · Enterale Ernährung · Parenterale Ernährung · Kombinierte Ernährungstherapie

\section{Results}

\section{Study population}

A detailed flowchart of the study is given in - Fig. 1. This study included 353 patients with severe sepsis or septic shock and length of ICU stay of more than 7 days with complete nutrition data collection.

\section{Patient characteristics}

- Tab. 1 summarizes the patient characteristics by the different types of nutrition therapy. The majority of patients received
$\mathrm{EN}+\mathrm{PN}(\mathrm{n}=242 ; 68.5 \%)$, whereof $233 \mathrm{pa}-$ tients were fed via the enteral and parenteral route on the same day and only 9 patients on different days. Patients in the $\mathrm{EN}$ and $\mathrm{EN}+\mathrm{PN}$ groups were significantly older and had a higher APACHE II score compared to the patients receiving exclusively PN. After exclusion of the age sub- 


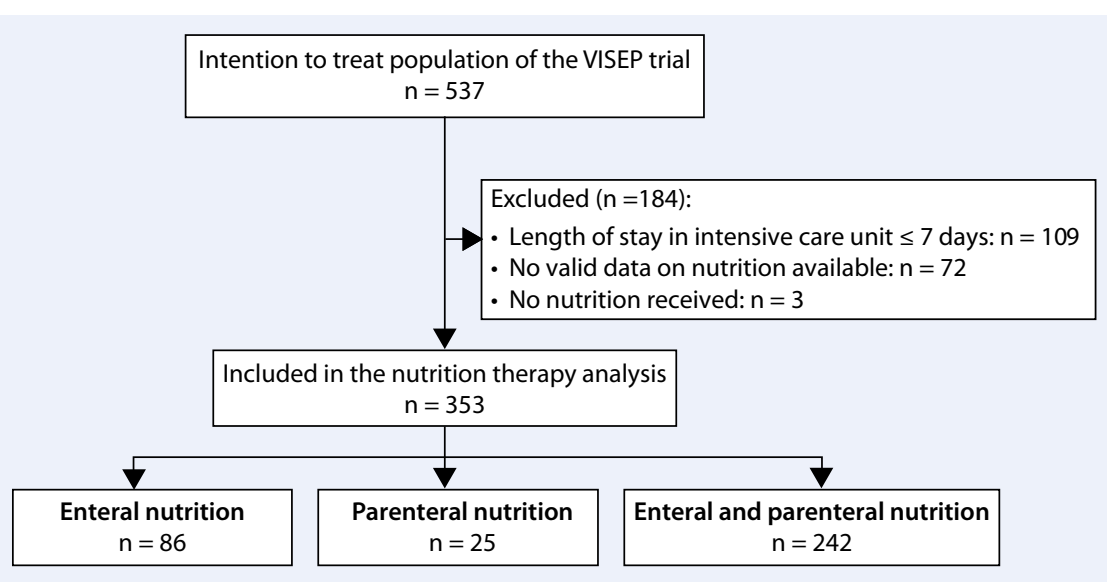

Fig. $1 \Delta$ Flowchart of study population

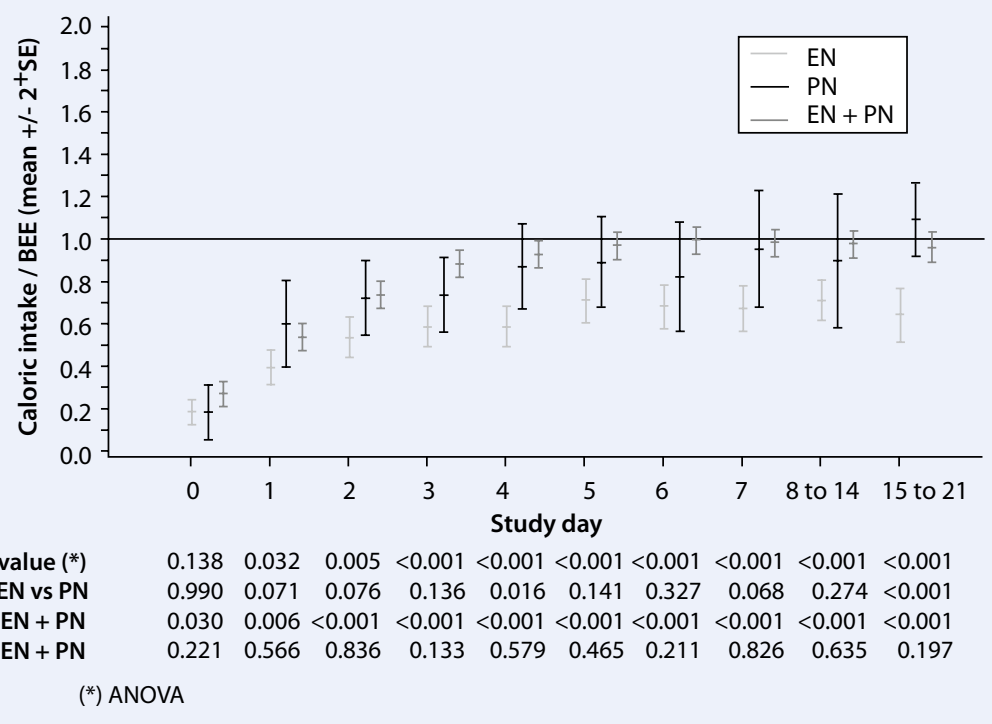

Fig. $2 \Delta$ Progression of daily caloric intake in relation to calculated basal energy expenditure (BEE). Mean ratios of daily caloric intake to $B E E$ over the 21 study days in patients receiving enteral nutrition (EN, light gray bar), parenteral nutrition (PN, black bar), and combined enteral and parenteral nutrition $(E N+P N$, dark gray bar). Day 0 represents the time from randomization until the start of the next full 24-h study day; $\mathrm{p}$ values below the diagram indicate the significance of differences among the types of nutrition therapy per study day. The bars denote mean values \pm 2 standard error (SE)

score, the median APACHE II score was 15 for $\mathrm{EN}$ and 16 for $\mathrm{EN}+\mathrm{PN}$ vs. 13 for the PN group ( $\mathrm{p}=0.043$ ). Significant differences among the different types of nutrition were also found with respect to the proportion of preexisting diabetes and the type of surgery.

\section{Nutrition therapy}

Details on nutrition therapy and metabolism are outlined in 0 Tab. 2. Median caloric intake and amount of protein were the highest for patients with $\mathrm{EN}+\mathrm{PN}$ $(1,343 \mathrm{kcal} /$ day and $48.3 \mathrm{~g} /$ day, respectively) and the lowest in the EN group (medi- a trend toward higher insulin doses was found for $\mathrm{PN}$ and $\mathrm{EN}+\mathrm{PN}$.

- Fig. 2 shows the daily progression of caloric intake among the different nutrition strategies during the study course and $\bullet$ Fig. 3 the daily proportion of calories administered by the enteral and parenteral route explicitly for patients with $\mathrm{EN}+\mathrm{PN}$. In this group, calories were predominantly administered by $\mathrm{PN}$ within the first study week.

\section{Outcomes}

- Tab. 3 summarizes the clinical outcomes. In patients with EN, the rate of renal-replacement therapy was significantly lowest $(20.9 \%, \mathrm{p}=0.048)$ and the number of ventilator-free days highest (median 4 days, $\mathrm{p}<0.001$ ). These patients also had significantly fewer secondary infections on days 7 and 14 in the ICU (32.0 and 37.3\%, $\mathrm{p}<0.001$ ) and the lowest overall mortality on days 28 and 90 (12.8 and $26.7 \%$, respectively, $\mathrm{p}=0.048$ ).

- Fig. 4 provides Kaplan-Meier analyses for overall survival (part a) and the proportion of patients without secondary infections (part b) according to the three groups of nutrition therapy.

In the adjusted Cox regression analysis, $\mathrm{EN}+\mathrm{PN}$ was associated with a higher mortality [adjusted hazard ratio $(\mathrm{HR})=1.86,95 \%$ confidence interval (CI): 1.16-2.98, $\mathrm{p}=0.010$ ] and a higher risk of secondary infections (HR=1.89 95\% CI: $1.27-2.81, p=0.002$ ) compared to EN (• Tab. 4). Due to the observed colinearity of the route and amount of nutrition, we deliberately did not adjust for caloric or protein intake, respectively, in the Cox regression model.

Accordingly, this resulted in a significantly higher ratio of mean daily caloric intake to calculated $\mathrm{BEE}$ by $\mathrm{EN}+\mathrm{PN}(0.9 ; 0.7-1.1)$ than by EN $(0.6 ; 0.4-0.9)$ or PN $(0.8 ; 0.5-$ $1.1, \mathrm{p}<0.001)$. Median total duration of nutrition therapy in the ICU was 16 days and significantly longest with 18 days in patients receiving $\mathrm{EN}+\mathrm{PN}$ compared to EN (14 days) and $\mathrm{PN}$ ( 8 days). Initiation of EN differed between EN (median day 1, IQR $0-1$ days) and $\mathrm{EN}+\mathrm{PN}$ (median day 3 , IQR $1-5$ days; $\mathrm{p}<0.001$ ). No significant imbalances were found for the maximum and minimum blood glucose levels, while

\section{Discussion}

The present study evaluated nutrition therapy and clinical outcomes in a mixed medical and surgical population of 353 patients with severe sepsis or septic shock and a length of ICU stay of more than 7 days. In this high-risk subgroup of critically ill patients, we found that $\mathrm{EN}+\mathrm{PN}$ was most frequently used with calories being administered early and predominantly via the parenteral route within the first 7 study days. In comparison to this strat- 


\begin{tabular}{|c|c|c|c|c|c|}
\hline Variable & Total & $\begin{array}{l}\text { Enteral } \\
\text { nutrition }\end{array}$ & $\begin{array}{l}\text { Parenteral } \\
\text { nutrition }\end{array}$ & $\begin{array}{l}\text { Enteral }+ \\
\text { parenteral } \\
\text { nutrition }\end{array}$ & $p$ value ${ }^{a}$ \\
\hline & $\begin{array}{l}n=353 \\
(100.0 \%)\end{array}$ & $\begin{array}{l}\mathrm{n}=86 \\
(24.4 \%)\end{array}$ & $\mathrm{n}=25(7.1 \%)$ & $\begin{array}{l}n=242 \\
(68.5 \%)\end{array}$ & \\
\hline \multicolumn{6}{|l|}{ Baseline characteristics } \\
\hline Age, years, median; IQR & $66 ; 56-74$ & $69 ; 57-76$ & $61 ; 50-64$ & $66 ; 56-73$ & 0.020 \\
\hline Gender, no. (\%) & & & & & \multirow[t]{3}{*}{0.647} \\
\hline Male & $219(62.0)$ & $56(65.1)$ & $17(68.0)$ & $146(60.3)$ & \\
\hline Female & $134(38.0)$ & $30(34.9)$ & $8(32.0)$ & $96(39.7)$ & \\
\hline \multicolumn{5}{|l|}{$\mathrm{BMI}, \mathrm{kg} / \mathrm{m}^{2}$} & \multirow[t]{2}{*}{0.333} \\
\hline Median; IQR & $26 ; 23-30$ & $25 ; 22-29$ & $27 ; 23-28$ & $26 ; 24-30$ & \\
\hline \multicolumn{5}{|l|}{ APACHE II } & \multirow[t]{2}{*}{0.002} \\
\hline Median; IQR & $19 ; 16-24$ & $20 ; 17-24$ & $16 ; 12-18$ & $20 ; 16-24$ & \\
\hline \multicolumn{5}{|l|}{ Creatinine clearance } & \multirow[t]{2}{*}{0.064} \\
\hline Median; IQR & $52 ; 34-86$ & $52 ; 36-88$ & $74 ; 54-111$ & $48 ; 33-79$ & \\
\hline \multicolumn{5}{|l|}{ Diabetes, no. (\%) } & \multirow[t]{2}{*}{$<0.001$} \\
\hline Either type & $97(27.5)$ & $36(41.9)$ & $2(8.0)$ & $59(24.4)$ & \\
\hline Type 1 & $41(11.6)$ & $14(16.3)$ & $1(4.0)$ & $26(10.7)$ & 0.005 \\
\hline Type 2 & $56(15.9)$ & $22(25.6)$ & $1(4.0)$ & $33(3.6)$ & \\
\hline \multicolumn{6}{|l|}{ Study intervention } \\
\hline \multicolumn{4}{|l|}{$\begin{array}{l}\text { Fluid resuscitation, no. } \\
\text { (\%) }\end{array}$} & & \multirow[t]{3}{*}{0.307} \\
\hline Ringer's lactate & $177(50.1)$ & $47(54.6)$ & $15(60.0)$ & $115(47.5)$ & \\
\hline HES & $176(49.9)$ & $39(45.4)$ & $10(40.0)$ & $127(52.5)$ & \\
\hline \multicolumn{5}{|l|}{ Insulin therapy, no. (\%) } & \multirow[t]{3}{*}{0.769} \\
\hline Conventional & $180(51.0)$ & $45(52.3)$ & $11(44.0)$ & $124(51.2)$ & \\
\hline Intensive & $173(49.0)$ & $41(47.7)$ & $14(56.0)$ & $118(48.8)$ & \\
\hline \multicolumn{5}{|l|}{$\begin{array}{l}\text { Admission category, } \\
\text { no. }(\%)\end{array}$} & \multirow[t]{4}{*}{0.780} \\
\hline Medical & $165(46.7)$ & $43(50.0)$ & $12(48.0)$ & $110(45.5)$ & \\
\hline Surgical & $187(53.0)$ & $43(50.0)$ & $13(52.0)$ & $131(54.1)$ & \\
\hline Missing & $1(0.3)$ & $0(0.0)$ & $0(0.0)$ & $1(0.4)$ & \\
\hline \multicolumn{5}{|l|}{ Type of surgery, no. $(\%)^{b}$} & \multirow[t]{4}{*}{$<0.001$} \\
\hline Gl or abdominal & $137(38.8)$ & $15(17.4)$ & $14(56.0)$ & $108(44.6)$ & \\
\hline Other & $124(35.1)$ & $50(58.1)$ & $4(16.0)$ & $70(28.9)$ & \\
\hline None & $91(25.8)$ & $21(24.4)$ & $6(24.0)$ & $64(26.4)$ & \\
\hline \multicolumn{5}{|l|}{$\begin{array}{l}\text { LOS ICU before study } \\
\text { entry, no. (\%) }\end{array}$} & \multirow[t]{5}{*}{0.215} \\
\hline 0 days & $101(28.6)$ & $19(22.1)$ & $7(28.0)$ & $75(31.0)$ & \\
\hline 1 day & $135(38.2)$ & $28(32.6)$ & $10(40.0)$ & $97(40.1)$ & \\
\hline 2 days & $27(7.7)$ & $8(9.3)$ & $2(8.0)$ & $17(7.0)$ & \\
\hline At least 3 days & $90(25.5)$ & $31(36.0)$ & $6(24.0)$ & $53(21.9)$ & \\
\hline \multicolumn{6}{|c|}{$\begin{array}{l}\text { Sum of patient numbers within a variable may be lower than total column patient number due to missing data } \\
B M I \text { body mass index, GI gastrointestinal, } H E S \text { hydroxyethyl starch, IQR interquartile range, LOS ICU length of } \\
\text { stay in the intensive care unitak Kruskal-Wallis, chi-square, or Fisher's exact test for differences among types of } \\
\text { nutrition therapy, as appropriate }{ }^{b} \text { During last } 30 \text { days before study inclusion }\end{array}$} \\
\hline
\end{tabular}

egy, patients who received EN alone, albeit resulting in a low calorie and protein intake according to current recommendations [23, 31], had a lower mortality and lower morbidity as measured by the rate of infectious complications, renal-replacement therapy, and ventilator-free days.
The recent large randomized-controlled "Early Parenteral Nutrition Completing Enteral Nutrition in Adult Critically Ill Patients" (EPaNIC) trial compared early (within $48 \mathrm{~h}$ ) vs. late initiation of PN (by day 8 after ICU admission) in combination with $\mathrm{EN}$ in a population of 4,640 mixed ICU patients [7]. The total study population comprised more than $60 \%$ cardiac surgery patients $(22 \%$ with sepsis upon ICU admission) with a short median ICU stay of 3-4 days and a 90-day mortality rate of only $11 \%$. In the absence of a mortality effect, the late PN group had a shorter ICU and hospital stay, length of mechanical ventilation, and renal-replacement therapy and fewer infectious complications. Although the amount of calories administered was generally markedly lower in our study, both our $\mathrm{EN}+\mathrm{PN}$ and their early initiation group were similar in terms of starting PN early (from day 1 on) and providing calories predominantly via this route in combination with $\mathrm{EN}$ within the first 7 days. Our results suggest that this approach is disadvantageous especially in the early disease phase of severely septic patients.

In contrast, previous observational studies suggested a better outcome with increased caloric and protein intake owing to the early supplemental or predominant use of $\mathrm{PN}$ in critically ill patients $[1,10,13,27,32,35]$. In the majority of these studies, only a limited number of severely septic patients were included. In a recent randomized-controlled trial, Singer et al. [30] evaluated whether nutrition therapy guided by repeated energy expenditure measurements (study group) as compared to protocol-guided nutrition prescription $(25 \mathrm{kcal} / \mathrm{kg} /$ day, control group) improved outcome. Their study comprised 130 critically ill patients $(22 \%$ with severe sepsis) with a minimum ICU stay of 3 days. A combination of EN and supplemental PN was used from study day 1 to reach the energy target in both groups. A trend toward lower hospital mortality was found in the study group, whereas the duration of mechanical ventilation, the length of ICU stay, and the infection rate were significantly increased. Compared to the control group, patients in the study group received more energy and protein because of more frequent use and a relatively higher daily proportion of supplemental PN. The reported increase in ventilation and ICU stay may simply be a function of an increased survival of the patients receiving $\mathrm{PN}$, as no adjustment was made for ventilator-free days or days in hospital but not in ICU. However, the 


\section{Originalien}

Tab. 2 Nutrition therapy and metabolism

Variable Total

Total Enteral nutrition

Parenteral nutrition

Enteral + parenteral nutrition p value $\mathrm{n}=353(100.0 \%) \quad \mathrm{n}=86(24.4 \%) \quad \mathrm{n}=25(7.1 \%) \quad \mathrm{n}=242(68.5 \%)$

\section{Mean daily caloric intake}

kcal

Median

IQR

1,199

918

$866-1,583$

627-1,161

1,210

$<0.001$

kcal/kg

Median

16.2

11.8

$745-1,735$

1,343

IQR

$11.1-21.3$

8.1-17.6

15.6

$<0.001$

Mean protein intake, $g$ /day

Median

IQR

42.4

33.6

$10.6-21.4$

$12.9-22.7$

$\mathrm{g} / \mathrm{kg} / \mathrm{day}$

26.1-61.3

$23.0-42.5$

33.3

$<0.001$

Median

IQR

0.57

0.43

$17.9-65.1$

48.3

Basal energy expenditure ${ }^{b}$

Kcal

Median

IQR

$0.33-0.84$

$0.29-0.64$

0.55

$<0.001$

$\mathbf{k c a l} / \mathbf{k g}$

Median

IQR

501

1,464

$0.16-0.90$

$29.3-66.8$

0.65

$0.37-0.96$

\section{Caloric intake/BEE}

Median

IQR

1,501

1,464

$1,295-1,662$

1,646

0.071

Proportion of calories administered

by enteral nutrition

\begin{tabular}{ll}
\hline Median \\
\hline IQR \\
\hline Parenteralnutition
\end{tabular}

$20 \quad 20 \quad 21 \quad 19$

$18-21$

$18-22$

$18-21$

$\begin{array}{llll}0.8 & 0.6 & 0.8 & 0.9\end{array}$

$\begin{array}{llll}0.6-1.1 & 0.4-0.9 & 0.5-1.1 & 0.7-1.1\end{array}$

\section{Parenteral nutrition}

Median 0.6

IQR

0.6

0.4

1.0

$1.0-1.0$

0.0

0.3

$0.1-1.0$

$0.0-0.0$

$0.1-0.6$

$0.6 \quad 0.0$

Duration of nutrition

Any type

Median; IQR

Enteral

Median; IQR

Parenteral

Median; IQR

$0.0-0.9$

0.0

$0.0-0.0$

1.0

$1.0-1.0$

0.7

$0.4-0.9$

First study day with nutrition

Any type

$\begin{array}{llcc}16 ; 9-20 & 14 ; 6-18 & 8 ; 6-16 & 18 ; 11-21 \\ 10 ; 5-16 & 14 ; 6-18 & 0 ; 0-0 & 10 ; 6-15 \\ 7 ; 1-15 & 0 ; 0-0 & 8 ; 6-16 & 10 ; 6-17\end{array}$

Median; IQR

$1 ; 0-1$

$1 ; 0-1$

$1 ; 0-1$

$0 ; 0-1$

Enteral nutrition

Median; IQR

$2 ; 0-5$

$1 ; 0-1$

$-$

$3 ; 1-5$

Parenteral nutrition

Median; IQR

$1 ; 0-2$

$1 ; 0-1$

$1 ; 0-2$

Enteral + parenteral

Nutrition

Median; IQR

$4 ; 2-7$

$-$

(2)

$-$

$-$

4 ; 2-7

Mean insulin dose, IU/day

Median

44.9
$26.5-64.4$

43.0

20.7-53.3

49.6

23.6-66.8

\section{5}

28.3-68.6 
Tab. 2 Nutrition therapy and metabolism (Continued)

\begin{tabular}{|c|c|c|c|c|c|}
\hline Variable & Total & Enteral nutrition & Parenteral nutrition & Enteral + parenteral nutrition & $\mathrm{p}$ value \\
\hline & $n=353(100.0 \%)$ & $n=86(24.4 \%)$ & $n=25(7.1 \%)$ & $n=242(68.5 \%)$ & \\
\hline Max blood glucose ${ }^{e} \mathrm{mg} / \mathrm{dl}$ & & & & & 0.400 \\
\hline Median & 161.2 & 156.4 & 154.0 & 162.8 & \\
\hline IQR & $142.9-196.5$ & $141.8-189.2$ & $141.7-186.0$ & $144.3-197.5$ & \\
\hline Min blood glucose $\mathrm{e}^{\mathrm{e}}$ & & & & & 0.503 \\
\hline \multicolumn{6}{|l|}{$\mathrm{mg} / \mathrm{dl}$} \\
\hline Median & 96.7 & 89.4 & 93.2 & 99.4 & \\
\hline IQR & $77.6-123.7$ & $78.5-114.4$ & $77.1-125.4$ & $59.7-164.3$ & \\
\hline
\end{tabular}

$B E E$ basal energy expenditure, IQR interquartile range, IU international units, max maximum, min minimumaKruskal-Wallis, chi-square, or Fisher's exact test for differences

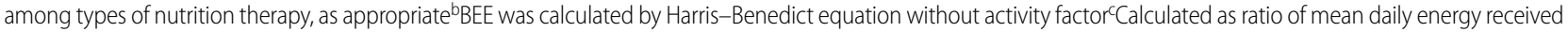
and calculated BEEd Calculated as mean of the daily dose for days with insulin therapye ${ }^{C}$ Calculated as the mean of the daily maximum or minimum glucose level, respectively

Tab. 3 Clinical outcome

\begin{tabular}{|c|c|c|c|c|c|}
\hline Variable & Total & Enteral nutrition & Parenteral nutrition & Enteral + parenteral nutrition & $p$ value \\
\hline & $n=353(100.0 \%)$ & $\mathrm{n}=86(24.4 \%)$ & $\mathrm{n}=25(7.1 \%)$ & $\mathrm{n}=242(68.5 \%)$ & \\
\hline Mean SOFA & & & & & 0.124 \\
\hline Median & 7 & 7 & 6 & 7 & \\
\hline IQR & $5-10$ & $5-9$ & $5-8$ & $5-10$ & \\
\hline Hypoglycemia $^{a}$ & & & & & 0.802 \\
\hline No. of patients (\%) & $37(10.5)$ & $10(11.6)$ & $3(12)$ & $24(9.9)$ & \\
\hline \multicolumn{6}{|l|}{ Renal replacement } \\
\hline No. of patients (\%) & $105(29.8)$ & $18(20.9)$ & $5(20)$ & $82(33.9)$ & 0.048 \\
\hline Ventilator-free days, median & 2 & 4 & 3 & 1 & $<0.001$ \\
\hline IQR & $0-6$ & $1-7$ & $0-7$ & $0-4$ & \\
\hline Secondary infection ${ }^{b}, \%$ & & & & & $<0.001$ \\
\hline \multicolumn{6}{|l|}{ At 7 days } \\
\hline Estimate & 39.5 & 32.0 & 32.9 & 42.8 & \\
\hline $95 \% \mathrm{Cl}$ & $34.6-44.9$ & $23.2-43.1$ & $18.0-55.3$ & $36.8-49.4$ & \\
\hline \multicolumn{6}{|l|}{ At 14 days } \\
\hline Estimate & 59.5 & 37.3 & 67.6 & 66.5 & \\
\hline $95 \% \mathrm{Cl}$ & $53.8-65.3$ & $27.5-49.2$ & $42.3-90.2$ & $59.8-73.1$ & \\
\hline \multicolumn{6}{|l|}{ LOSICU $^{\mathrm{b}}$, days } \\
\hline Median & 26 & 20 & 12 & 30 & $<0.001$ \\
\hline IQR & $14-48$ & $13-28$ & $10-45$ & $16-54$ & \\
\hline Overall mortality $^{\mathrm{b}}, \%$ & & & & & 0.048 \\
\hline \multicolumn{6}{|l|}{ At 28 days } \\
\hline Estimate & 21.0 & 12.8 & 16.0 & 24.4 & \\
\hline $95 \% \mathrm{Cl}$ & $17.1-25.6$ & $7.3-21.9$ & $6.3-37.2$ & $19.5-30.3$ & \\
\hline \multicolumn{6}{|l|}{ At 90 day } \\
\hline Estimate & 37.1 & 26.7 & 32.0 & 41.3 & \\
\hline $95 \% \mathrm{Cl}$ & $32.3-42.4$ & $18.7-37.4$ & $17.5-53.9$ & $35.4-47.8$ & \\
\hline
\end{tabular}

IQR interquartile range, LOS ICU length of stay in the intensive care unit, SOFA Sequential Organ Failure AssessmentaHypoglycemia defined as blood glucose level $\leq 40 \mathrm{mg} /$ dl $(2.2 \mathrm{mmol} /)^{\mathrm{b}}$ Estimated by the Kaplan-Meier method

authors attributed the increased morbidity of the study group in part to the higher metabolic load that actually exceeded the measured energy target within the first week. The most recent bicenter randomized-controlled trial by Heidegger et al. enrolled 305 critically ill patients with an ICU stay of 3 days or more and compared
EN supplemented by PN (SPN group) for coverage of energy target from day 4 to day 8 after ICU admission with EN alone [17]. Energy target was measured by indirect calorimetry in $65 \%$ of the patients or set to 25 (women) and 30 (men) kcal/ kg ideal bodyweight, respectively. Patients in the SPN group received significantly more energy between days 4 and 8 (mean $28 \mathrm{kcal} / \mathrm{kg} /$ day vs. $20 \mathrm{kcal} / \mathrm{kg} /$ day in the EN group). No mortality difference was found, but patients in the SPN group had fewer nosocomial infections, less number of antibiotic days, and a shorter duration of mechanical ventilation. The differences in outcome between the study by 


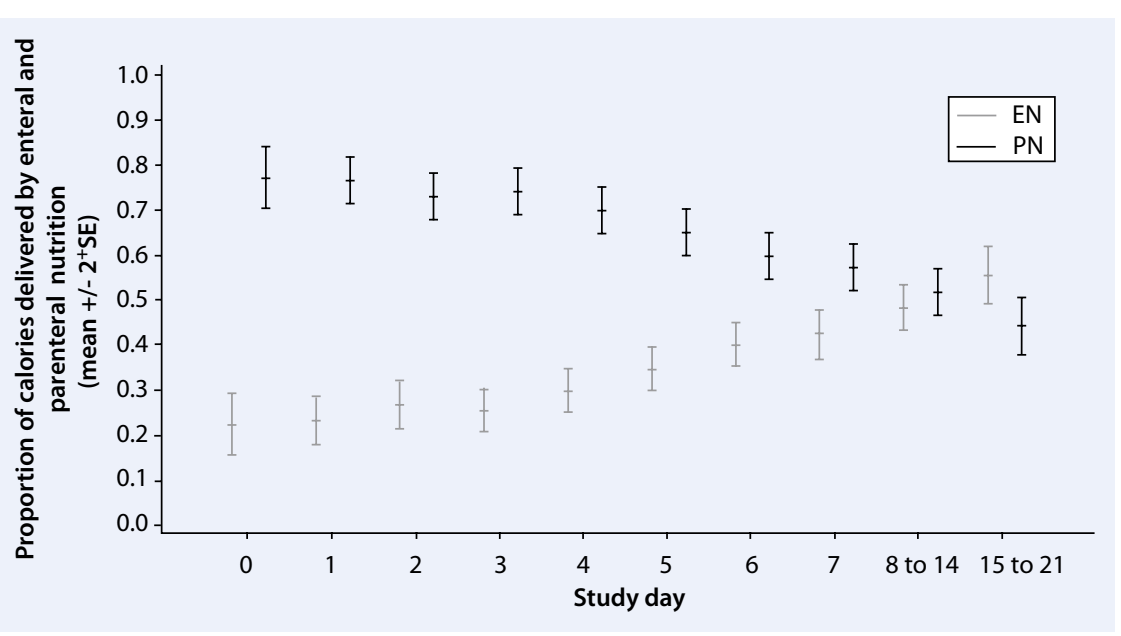

Fig. $3 \Delta$ Proportion of calories delivered by the enteral ( $E N$, light gray bar) and parenteral route ( $P N$, black bar) in the patients receiving combined nutrition therapy ( $E N+P N$ group). Day 0 represents the time from randomization until the start of the next full 24 -h study day. The bars denote mean values \pm 2 standard error (SE)

Heidegger et al. and our study might be mainly explained by the different patient population studied and the time point of starting $\mathrm{PN}$ in combination with EN. We only included patients with severe sepsis and septic shock, which likely accounts for the generally higher mortality observed in our study ( $21 \%$ vs. $16 \%$ at 28 days). Unlike their SPN group where PN was delayed until day 4, patients in our $\mathrm{EN}+\mathrm{PN}$ group received $\mathrm{PN}$ early in the course of sepsis from day 1 on.

The negative effects of $\mathrm{PN}$ given as primary or supplementary therapy have been mainly linked to metabolic stress resulting from hyperalimentation with consecutive hyperglycemia and increased infectious complications, particularly during the early phase of critical illness [36]. In the presence of glycemic control, potential overfeeding might be indicated by metabolic stress markers such as higher insulin requirements, as suggested by previous studies [3,11]. In our study, a trend toward higher insulin doses was observed with $\mathrm{EN}+\mathrm{PN}$ or $\mathrm{PN}$, whereby the randomized treatment arms (intensive and conventional insulin therapy) and the range of serum blood glucose (i.e., daily minimum and maximum values) were not significantly different, as was the rate of hypoglycemia.

Singer et al. [29] hypothesized that a transient metabolic shutdown is necessary for cell survival during severe sepsis similar to a state of hibernation [24].
According to this hypothesis it is likely that the energy requirements of our patients were markedly reduced since they were enrolled within the first $24 \mathrm{~h}$ after the onset of severe sepsis or septic shock. Kreyman et al. [19] showed that energy expenditure decreases with severity of illness resulting in prevailing hypometabolism in patients with severe sepsis and septic shock. One may speculate that a lower caloric intake by EN especially in the early phase of illness could be sufficient to maintain basal metabolism for survival and prevent metabolic stress.

The adverse outcome of the patients with $\mathrm{EN}+\mathrm{PN}$ may also be explained by complications unrelated to hyperglycemia. In septic patients, the use of PN was associated with an increased risk of liver dysfunction [15] while low-dose enteral nutrition maintained the gastric mucosal balance and improved systemic and hepatosplanchnic blood flow [26]. PN may exhibit considerable hazard when given to patients with a functioning gastrointestinal tract, and this may have applied to $55.3 \%$ of the surgical patients with $\mathrm{EN}+\mathrm{PN}$ who had no history of abdominal surgery present at study entry. On the contrary, the remaining patients with $\mathrm{EN}+\mathrm{PN}$ were admitted with a history of abdominal surgery, implying that the decision of combined feeding was based on the presence of gastrointestinal dysfunction. In such patients with gastrointestinal dysfunction, Kutsogiannis et al. re- cently demonstrated that both early and late supplemental PN were still found to be associated with worsening outcomes in an observational study of 2,920 critically ill patients (9\% with sepsis) [21].

In the absence of a standardized nutrition protocol, not only the caloric intake but also the median protein intake in our study population was generally low according to current recommendations for protein administration in critically ill patients [20, 31]. It remains uncertain to what extent this has affected our results. However, the optimal goal of protein administration and possible impact on the inflammatory response in patients with severe sepsis still remains unknown and has not been addressed by randomizedcontrolled trials so far. In a retrospective study of 295 patients (34\% with sepsis) remaining in the ICU for more than 7 days, Tsai et al. did not find differences in clinical outcomes with respect to protein delivery [34]. Neither did the very large observational study by Kutsogiannis et al., despite an improved delivery of $80 \%$ of the prescribed protein intake with supplemental PN [21].

\section{Limitations}

The main limitation is the design of our study. We are unable to imply causality to the association found because residual confounding due to inhomogeneous patient characteristics among the nutrition groups may still exist despite the adjustment for various covariates. Only a randomized-controlled trial of severely septic patients designed to separate the effects of the different route and amount of nutrition may corroborate our hypothesis-generating results. Owing to the low number of patients receiving $\mathrm{PN}$ only, the analysis lacks in power for the comparison of $\mathrm{EN}$ vs. $\mathrm{PN}$ and $\mathrm{EN}+\mathrm{PN}$ vs. PN. We therefore focused on the comparison of EN and $\mathrm{EN}+\mathrm{PN}$, but presented data on $\mathrm{PN}$ for the sake of completeness.

A further limitation is that no standardized nutrition protocol was specifically followed in the study but investigators agreed to base their patients' management on the international guidelines for the diagnosis and treatment of severe sepsis [33]. This included the preferential use 
a

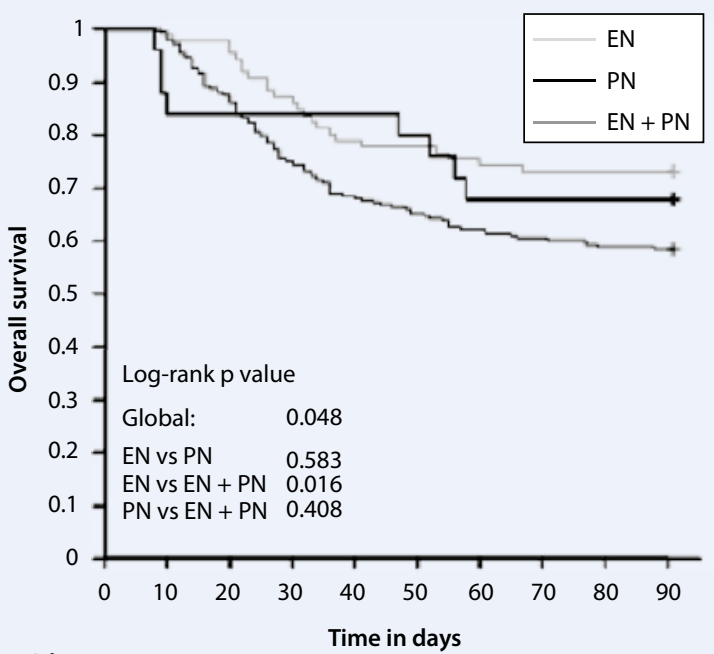

Patients at risk

$\begin{array}{rrrrrrrrrrr}\text { EN } & 86 & 85 & 84 & 75 & 68 & 67 & 65 & 63 & 63 & 63 \\ \text { PN } & 25 & 22 & 21 & 21 & 21 & 20 & 17 & 17 & 17 & 17 \\ \text { EN + PN } & 242 & 241 & 212 & 182 & 166 & 158 & 151 & 147 & 143 & 142\end{array}$

b

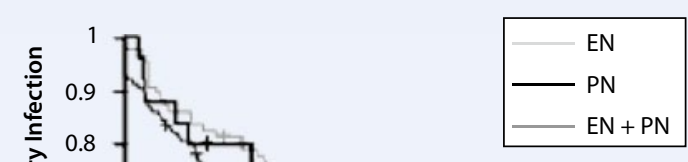

Patients at risk

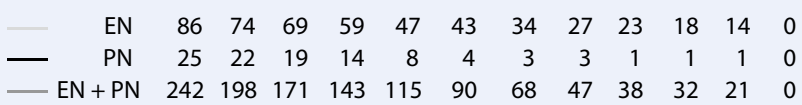

Fig. $4 \Delta$ Kaplan-Meier curves for overall survival and secondary infections. Overall survival (a) and the proportion of patients without secondary infections (b) among the patients receiving enteral ( $E N$, light gray line), parenteral ( $P N$, black line), or combined nutrition therapy $(E N+P N$, dark gray line). $P$ values calculated by the log-rank test are displayed in each diagram

of EN as well as using PN for those patients intolerant to EN or with contraindications. Our study also lacks more detailed information on the specific formulations used including supplementary immunonutrition and administration of prokinetics in the different groups. Moreover, actual energy expenditure was not measured by indirect calorimetry but only calculated using the Harris-Benedict equation. This static approach only estimates the patient's metabolic activity, and current guidelines $[23,31]$ recommend the routine use of indirect calorimetry albeit this technique is not commonly available in many ICUs. Initiation of $\mathrm{EN}$ differed between patients with $\mathrm{EN}$ and $\mathrm{EN}+\mathrm{PN}$, which might have influenced our results. However, Cahill et al. were able to show that even late EN alone ( $>48 \mathrm{~h}$ ), as compared to either late $(>48 \mathrm{~h})$ or early $(<48 \mathrm{~h})$ supplemental PN, tended to decrease mortality in medical ICU patients with an ICU stay longer than 3 days [6]. Finally, the patients' nutritional status before study entry was only characterized by the BMI at study entry that was in the range of $23-30 \mathrm{~kg} / \mathrm{m}^{2}$. We acknowledge that our results may not apply to severely septic patients with preexisting protein-energy malnutrition or obesity, who might profit from a daily increased energy and protein administration [1].
The strength of our study is the focus on a large study population of patients with severe sepsis or septic shock remaining at least 7 days in the ICU and that the data on nutrition therapy were prospectively collected for up to 21 ICU days.

\section{Conclusion}

- This secondary analysis of the VISEP trial revealed that the early and predominant use of parenteral nutrition combined with enteral nutrition resulted in a higher caloric intake in patients with severe sepsis and septic shock and prolonged ICU stay compared to early enteral nutrition alone.

- However, the use of enteral nutrition alone was associated with improved outcome in this specific subgroup of critically ill patients.

- These hypothesis-generating results have to be confirmed by a randomized-controlled trial in a homogeneous patient population of only severely septic patients.

\section{Corresponding address}

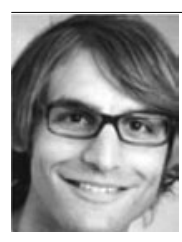

\section{Dr. G. Elke}

Department of

Anaesthesiology and Intensive Care Medicine, University Medical Centre SchleswigHolstein, Campus Kiel Arnold-Heller-Str. 3, Haus 12, Schwanenweg 21, 24105 Kiel Germany gunnar.elke@uksh.de

Acknowledgments. The VISEP trial was supported by the Federal Ministry of Education and Research, Berlin, Germany, (BMBF, grant no. $01 \mathrm{KI}$ 0106) and unrestricted grants from B. Braun Melsungen, HemoCue, NovoNordisk. F.M.B. is head of the Paul Martini Sepsis Research Group, funded by the Thuringian Ministry of Education, Science and Culture (ProExcellence; PE 108-2), the Thuringian Foundation for Technology, Innovation and Research (STIFT), and the German Sepsis Society (GSS).

Conflict of interest. On behalf of all authors, the corresponding author states the following: G.E. received speaker's honoraria from Abbott, B. Braun, and Fresenius Kabi. All other authors declare that they have no conflict of interest.

\section{References}

1. Alberda C, Gramlich L, Jones N et al (2009) The relationship between nutritional intake and clinical outcomes in critically ill patients: results of an international multicenter observational study. Intensive Care Med 35:1728-1737 
Originalien

Tab. 4 Cox model of overall mortality and secondary infections in patients with ICU LOS of more than 7 days

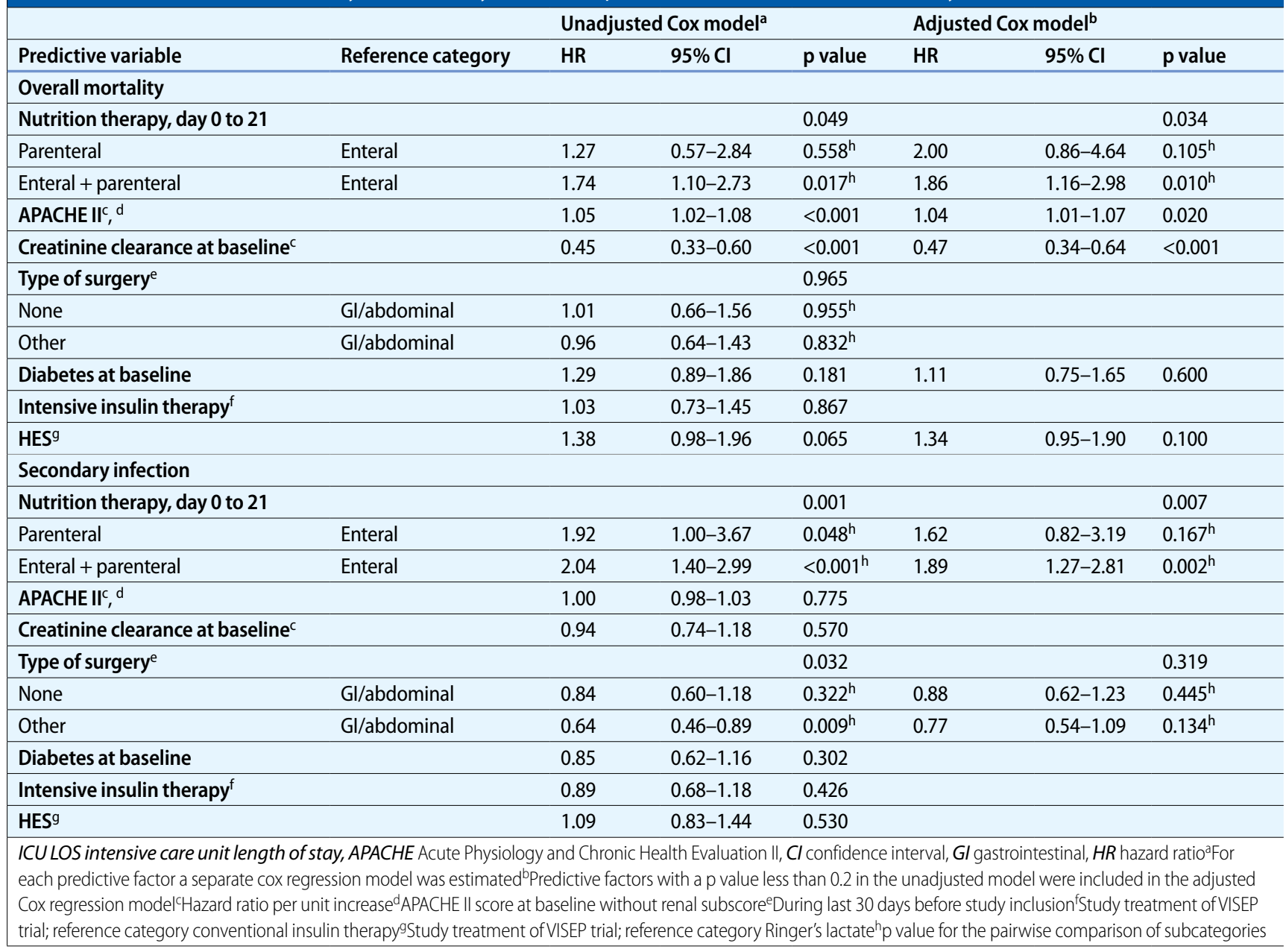

2. (n d) (1992) American College of Chest Physicians/ Society of Critical Care Medicine Consensus Conference: definitions for sepsis and organ failure and guidelines for the use of innovative therapies in sepsis. Crit Care Med 20:864-874

3. Arabi YM, Haddad SH, Tamim HM et al (2010) Neartarget caloric intake in critically ill medical-surgical patients is associated with adverse outcomes. JPEN J Parenter Enteral Nutr 34:280-288

4. Brunkhorst FM, Engel C, Bloos F et al (2008) Intensive insulin therapy and pentastarch resuscitation in severe sepsis. N Engl J Med 358:125-139

5. Brunkhorst FM, Gastmeier P, Kern W et al (2010) Prevention and follow-up care of sepsis. 1st revision of S2k guidelines of the German Sepsis Society (Deutsche Sepsis-Gesellschaft e. V., DSG) and the German Interdisciplinary Association of Intensive Care and Emergency Medicine (Deutsche Interdisziplinare Vereinigung fur Intensiv- und Notfallmedizin, DIVI). Internist (Berl) 51:925-932

6. Cahill NE, Murch L, Jeejeebhoy K et al (2011) When early enteral feeding is not possible in critically ill patients: results of a multicenter observational study. JPEN J Parenter Enteral Nutr 35:160-168

7. Casaer MP, Mesotten D, Hermans G et al (2011) Early versus late parenteral nutrition in critically ill adults. N Engl J Med 365:506-517
8. Dellinger RP, Levy MM, Carlet JM et al (2008) Surviving Sepsis Campaign: international guidelines for management of severe sepsis and septic shock: 2008. Crit Care Med 36:296-327

9. Dissanaike S, Shelton M, Warner K, O'Keefe GE (2007) The risk for bloodstream infections is associated with increased parenteral caloric intake in patients receiving parenteral nutrition. Crit Care 11:R114

10. Dvir D, Cohen J, Singer P (2006) Computerized energy balance and complications in critically ill patients: an observational study. Clin Nutr 25:37-44

11. Elke G, Schadler D, Engel C et al (2008) Current practice in nutritional support and its association with mortality in septic patients—results from a national, prospective, multicenter study. Crit Care Med 36:1762-1767

12. Engel JM, Muhling J, Junger A et al (2003) Enteral nutrition practice in a surgical intensive care unit: what proportion of energy expenditure is delivered enterally? Clin Nutr 22:187-192

13. Faisy C, Lerolle N, Dachraoui F et al (2009) Impact of energy deficit calculated by a predictive method on outcome in medical patients requiring prolonged acute mechanical ventilation. $\mathrm{Br} J$ Nutr 101:1079-1087
14. Gramlich L, Kichian K, Pinilla J et al (2004) Does enteral nutrition compared to parenteral nutrition result in better outcomes in critically ill adult patients? A systematic review of the literature. Nutrition 20:843-848

15. Grau T, Bonet A, Rubio M et al (2007) Liver dysfunction associated with artificial nutrition in critically ill patients. Crit Care 11:R10

16. Heidegger CP, Darmon P, Pichard C (2008) Enteral vs. parenteral nutrition for the critically ill patient: a combined support should be preferred. Curr Opin Crit Care 14:408-414

17. Heidegger CP, Berger MM, Graf $S$ et al (2012) Optimisation of energy provision with supplemental parenteral nutrition in critically ill patients: a randomised controlled clinical trial. Lancet; published online Dec 3. http://dx.doi.org/10.1016/ S0140-6736(12)61351-8

18. Heyland DK, Cahill N, Day AG (2011) Optimal amount of calories for critically ill patients: depends on how you slice the cake! Crit Care Med 39:2619-2626

19. Kreymann G, Grosser S, Buggisch P et al (1993) Oxygen consumption and resting metabolic rate in sepsis, sepsis syndrome, and septic shock. Crit Care Med 21:1012-1019

20. Kreymann KG, Berger MM, Deutz NE et al (2006) ESPEN guidelines on enteral nutrition: intensive care. Clin Nutr 25:210-223 
21. Kutsogiannis J, Alberda C, Gramlich L et al (2011) Early use of supplemental parenteral nutrition in critically ill patients: results of an international multicenter observational study. Crit Care Med 39:2691-2699

22. McClave SA, Heyland DK (2009) The physiologic response and associated clinical benefits from provision of early enteral nutrition. Nutr Clin Pract 24:305-315

23. McClave SA, Martindale RG, Vanek VW et al (2009) Guidelines for the provision and assessment of nutrition support therapy in the adult critically III patient: Society of Critical Care Medicine (SCCM) and American Society for Parenteral and Enteral Nutrition (A.S.P.E.N.). JPEN J Parenter Enteral Nutr 33:277-316

24. Mongardon N, Singer M (2010) The evolutionary role of nutrition and metabolic support in critical illness. Crit Care Clin 26:443-450, vii-viii

25. O'Meara D, Mireles-Cabodevila E, Frame F et al (2008) Evaluation of delivery of enteral nutrition in critically ill patients receiving mechanical ventilation. Am J Crit Care 17:53-61

26. Rokyta RJ, Matejovic M, Krouzecky A et al (2004) Post-pyloric enteral nutrition in septic patients: effects on hepato-splanchnic hemodynamics and energy status. Intensive Care Med 30:714-717

27. Scheinkestel CD, Kar L, Marshall K et al (2003) Prospective randomized trial to assess caloric and protein needs of critically III, anuric, ventilated patients requiring continuous renal replacement therapy. Nutrition 19:909-916

28. Sena MJ, Utter GH, Cuschieri J et al (2008) Early supplemental parenteral nutrition is associated with increased infectious complications in critically ill trauma patients. J Am Coll Surg 207:459-467

29. Singer M, De Santis V, Vitale D, Jeffcoate W (2004) Multiorgan failure is an adaptive, endocrine-mediated, metabolic response to overwhelming systemic inflammation. Lancet 364:545-548

30. Singer P, Anbar R, Cohen J et al (2011) The tight calorie control study (TICACOS): a prospective, randomized, controlled pilot study of nutritional support in critically ill patients. Intensive Care Med 37:601-609

31. Singer $P$, Berger $M M$, Van den Berghe $G$ et al (2009) ESPEN guidelines on parenteral nutrition: intensive care. Clin Nutr 28:387-400

32. Strack van Schijndel RJ, Weijs PJ, Koopmans RH et al (2009) Optimal nutrition during the period of mechanical ventilation decreases mortality in critically ill, long-term acute female patients: a prospective observational cohort study. Crit Care 13:R132

33. The International Sepsis Forum (2001) Guidelines for the management of severe sepsis and septic shock. Intensive Care Med 27(Suppl 1):S1-134

34. Tsai JR, Chang WT, Sheu CC et al (2011) Inadequate energy delivery during early critical illness correlates with increased risk of mortality in patients who survive at least seven days: a retrospective study. Clin Nutr 30:209-214

35. Villet S, Chiolero RL, Bollmann MD et al (2005) Negative impact of hypocaloric feeding and energy balance on clinical outcome in ICU patients. Clin Nutr 24:502-509

36. Ziegler TR (2009) Parenteral nutrition in the critically ill patient. N Engl J Med 361:1088-1097

\section{Fred Salomon (Hrsg.) \\ Praxisbuch Ethik in der Intensivmedizin}

Konkrete Entscheidungshilfen

in Grenzsituationen

Berlin: Medizinisch Wissenschaftliche Verlagsgesellschaft 2012, 2. Auflage, 392 S., 36 Abb., 31 Tab., (ISBN 978-3-941468-74-0), 49.00 EUR

Kaum eine andere Thematik wie die Ethik in der Intensivmedizin hat in den vergangenen Jahren eine solche zentrale Bedeutung erlangt.

Jede Ärztin, jeder Arzt, muss täglich multiple ethisch geprägte Entscheidungen nicht nur in der Intensivmedizin treffen, die zum Teil von erheblichem Gewicht sind und die Prognose von Patienten betreffen.

Es ist gut, dass sich die sehr hierarchisch und paternalistisch geprägte Medizin in den letzten Jahren zunehmend verändert, Patienten und ihre Angehörigen haben gerade in der Intensivmedizin ein enormes Gewicht bekommen, dabei spielt vor allen Dingen der Patientenwille, die Autonomie des Patienten, eine zentrale Rolle.

Sicherlich waren die lange geführten Diskussionen vor Verabschiedung der Novellierung des Betreuungsrechts vom 29. Juli 2009 ausschlaggebend, dass die Problematik zunehmend auch in das Bewusstsein einer breiten

Öffentlichkeit getreten ist.

Fred Salomon als Herausgeber ist es gelungen, in einem kompakten aber sehr umfassenden Werk, mit verschiedenen hervorragenden und renommierten Autoren, ein aktuelles und fesselndes, sehr praktisch orientiertes "Lehrbuch" zu Ethik in der Intensivmedizin zu verfassen.

Dieses Buch erscheint zu Recht nun schon in der 2. und aktualisierten Auflage -offensichtlich hat es eine große Leserschaft angesprochen- und beim erneuten Lesen der außerordentlich guten und exzellent geschriebenen Beiträge bestätigt sich der Eindruck, den der Leser schon bei der 1. Auflage gewonnen hat: Dieses Buch bietet zahllose relevante Informationen für den/die praktisch tätigen Intensivmediziner/in und sollte sicherlich auf jeder Intensivstation den dort tätigen Ärzten zur Verfügung gestellt werden. Aber nicht nur für Ärzte ist dieses Buch lesenswert, auch für das gesamte Behandlungsteam sind die Beiträge außerordentlich wertvoll und können wichtige Impulse leisten, um die tägliche, zum Teil sehr schwere Arbeit mit kritisch kranken Patientinnen und Patienten am Lebensende besser gestalten zu können.

Neben propädeutischen Beiträgen zur Menschenwürde auf der Intensivstation, bzw. dem Menschenbild als Entscheidungshintergrund intensivmedizinischen Handelns, finden sich konkrete Hilfen zur Umsetzung palliativmedizinischer Konzepte oder Begleitung Sterbender in der Intensivmedizin, aber auch in Bezug auf Angehörige und den alten Menschen.

Auch rechtliche Aspekte werden umfangreich thematisiert, so dass nach Lesen dieses Buches nur wenige Fragen übrig bleiben, die sicherlich in einer bald erscheinenden 3. Auflage ihre Vervollständigung erfahren werden. Also: sicherlich ein hervorragendes Werk, welches unbedingt nicht nur gelesen, sondern auch im klinischen Alltag umgesetzt gehört.

Eine wertvolle Hilfe im klinischen Alltag!

iCAMPUS (Bonn) 